\title{
Can income diversification resolve social-ecological traps in small-scale fisheries and aquaculture in the global south? A case study of response diversity in the Tam Giang lagoon, central Vietnam
}

\author{
Tong Thi Hai Hanh ${ }^{1}$ and Wiebren J. Boonstra ${ }^{1,2}$
}

\begin{abstract}
Small-scale fishers and aquaculturists in the global south often face reinforcing feedbacks between resource degradation and livelihood impoverishment, a situation conceptualized as a social-ecological trap. It is argued that these traps can be overcome through income diversification, i.e., livelihoods that are maintained from variable income sources. Our aim was to further scrutinize that claim using the concept of response diversity. To do so, we applied the concept and analyzed income diversification in the Tam Giang lagoon, central Vietnam. Based on our analysis, we argue that high diversity in income activities does not necessarily lead to an escape from social-ecological traps. Although diversity in income activities in the case of the Tam Giang lagoon is relatively high, fisheries- and aquaculture-related income activities continue to dominate livelihood portfolios. The various gear and structures that these activities include all exploit the same ecologies, habitats, and niches of the lagoon. This finding triggers questions concerning the relative contribution of income activities to household income, but also how activities are (differently) connected to natural environments. Income diversification can only sustain natural resources and improve human well-being if it truly transforms livelihoods by connecting local users in new ways to ecologies and societies.
\end{abstract}

Key Words: global south; income diversification; response diversity; small-scale aquaculture; small-scale fisheries; social-ecological traps; Tam Giang lagoon

\section{INTRODUCTION}

Small-scale fisheries and aquaculture directly or indirectly maintain livelihoods for about 500 million people living in the global south (World Bank 2009). For this reason, small-scale fisheries and aquaculture are considered central means for poverty alleviation and livelihood improvement in the global south (Allison and Ellis 2001, Béné et al. 2010, Food and Agriculture Organization of the United Nations [FAO] 2014). However, an increasing deterioration of marine and estuary resources negatively impacts the resilience of both livelihood activities and contributes to further impoverishment (Barbier 2015). Of all the fish stocks globally, $61.3 \%$ are currently fully fished, $28.8 \%$ are overfished, and only $9.9 \%$ are underfished (FAO 2014), while aquaculture contributes to the loss of valuable ecosystems such as mangrove forest and ecosystem services (ESs) such as freshwater (van Wesenbeeck et al. 2015, Marschke and Betcherman 2016). Consequently, many fishers and aquaculturists in the global south struggle with reinforcing feedbacks between resource degradation and livelihood impoverishment, a situation that often resembles a social-ecological trap (Cinner 2011, Kittinger et al. 2013, Laborde et al. 2016).

Social-ecological traps refer to "situations when feedback between social and ecological systems lead toward an undesirable state that maybe difficult or impossible to reverse" (Cinner 2011:835). The reinforcing feedback between environmental change and human response is the causal mechanism that makes a trap deterministic (Fraser et al. 2003, Boonstra et al. 2016). A classic example of a social-ecological trap is the so-called povertyenvironmental degradation nexus (Duraiappah 1998, Dasgupta et al. 2005, Cumming et al. 2014), which, stripped of its inherent complexity and context dependence, is captured in the following statement: "Poor people are forced to overuse environmental resources to survive from day to day, and the impoverishment of their environment further impoverishes them, making their survival ever more difficult and uncertain" (World Commission on Environment and Development 1987:27).

Lack of alternative income is frequently considered as a central mechanism producing trap dynamics between poverty and resource degradation in both development economics and sustainability science (Haider et al. 2018). Income diversification is therefore recognized as a strategy for dealing with resource degradation and poverty (Ellis 2000, Allison and Ellis 2001). Income diversification has been explored in fisheries literature, yet studies have focused on social benefits, such as income increase, improvement in well-being, and reduction of conflicts over resources (Allison and Ellis 2001). The exclusive attention to social effects can overshadow how an increase of social resilience can occur at the expense of ecological resilience (Folke et al. 2003). Moreover, there are a great variety of ways in which people diversify their income or livelihoods (Boonstra et al. 2016, Haider et al. 2018). It follows that different types of income diversification also have different social and ecological impacts.

Our aim is to further scrutinize the claim that income diversification can help resolve trap dynamics related to poverty and environmental degradation in small-scale fisheries and aquaculture in the global south. For this purpose, we apply the concept of response diversity in a case study of the development of fishers' and aquaculturists' livelihoods in the Tam Giang lagoon, Vietnam. The concept of response diversity allows us to consider the various ways in which income diversification is interdependent with social-ecological dynamics beyond the rural household and livelihoods. Moreover, because response diversity is theoretically linked to resilience, the concept also helps us to

${ }^{1}$ Department of Earth Sciences, Program for Natural Resources and Sustainable Development, Uppsala University, Sweden, ${ }^{2}$ Stockholm Resilience Centre 
consider conditions where income diversification can either transform or reinforce trap dynamics. It facilitates a critical assessment of income diversification and its effect on social and ecological sustainability.

We first review empirical and theoretical debates on the role of response diversity in relation to social-ecological traps. Second, we describe social-ecological trap dynamics in the Tam Giang lagoon, followed by a description of the methods used to collect data and information for our case study. Third, we present an analysis of the various ways of income diversification of resource users in the lagoon and their effects on trap dynamics. Fourth, we discuss our results in relation to the theorization of response diversity and the resolution of social-ecological traps. Based on findings from the case study of local resource use in the Tam Giang lagoon, we conclude that income diversification can have adverse effects on trap dynamics when it relies heavily on a single ecosystem.

\section{RESPONSE DIVERSITY AND RESILIENCE}

The underlying idea of income diversification as a major strategy to overcome trap dynamics in primary resource use, especially in the global south (Lybbert et al. 2004, Barrett et al. 2006, Carter et al. 2007, Barrett 2008, Cinner et al. 2009, Swallow et al. 2009, Tittonell and Giller 2013), is that rural households by obtaining their income from various activities manage to spread risk and to better cope with sudden changes, from natural disasters, sickness, or economic crises (Kasperski and Holland 2013). Despite that this claim is well established, especially in studies of fisheries in the global south (Cinner and Bodin 2010), recent studies have raised questions concerning the exclusive economic focus of the argument for income diversification (Haider et al. 2018) and the tension that exists between improvement of well-being through income diversification and ecological sustainability (Coulthard 2012, Coulthard and Britton 2015). It follows from these recommendations that analyses of trap dynamics in small-scale fisheries and aquaculture in the global south would do well to consider how income diversification relates to and impacts both well-being and ecological sustainability. To do so, we turn to the concept of response diversity.

Generally, diversity is understood as a basic principle of resilience in social-ecological interactions (Elmqvist et al. 2003, Biggs et al. 2012). Sustainability scientists emphasize the importance of diversity because their ecological studies demonstrate how variability in behavior of organisms structures the natural environment. The idea is that "what organisms do" is functionally related to system-level properties of ecosystems, such as resilience; this is why ecologists often talk about "functional diversity" (Petchey and Gaston 2006). When they focus more specifically on the variability in how organisms respond to environmental change, they use the term "response diversity." Response diversity is then defined as "the diversity of response to environmental change among species that contribute to the same ecosystem function" (Elmqvist et al. 2003:448).

Recently, the term response diversity has been applied in the social sciences as well to express the variation of human decisions and actions to environmental changes. Here, response diversity is used to capture the notion that "not all actors respond the same way to challenges, opportunities and risks" (Leslie and McCabe
2013:1). Response diversity is often preferred over functional diversity for the analysis of human social behavior because the former is applied to understand between-species variability, whereas the latter refers to within-species variability (Leslie and McCabe 2013). Moreover, a focus on functional diversity does not align as well with social science approaches that are critical of explaining behavior solely in terms of its functional relevance for maintaining social-ecological structures or systems (Fabinyi et al. 2014, Orr et al. 2015). With its connection to resilience, the term facilitates consideration of how social diversity is interdependent with wider social-ecological interactions (Mori et al. 2013).

It is through its connection to resilience that we believe response diversity can be useful for assessing the effect of income diversification on trap dynamics. Trap dynamics refer to interactions between social and environmental factors that are resilient, i.e., interactions that have become rigid and withstand change. It follows that it is essential to assess how response diversity affects resilience. Leslie and McCabe (2013) argue that response diversity among human populations could increase diversity. As they state, "Response diversity within and among human communities introduces the possibility of 'heterogenization' of the landscape in some cases, which could in turn either increase or decrease species diversity at given scales" (Leslie and McCabe 2013:128). That is to say, through increasing diversity, response diversity contributes to the resilience of social-ecological systems. However, the interrelation between diversity and resilience is complex and uncertain. With the example of the interrelation between diversity and resilience of ESs, Kotschy et al. (2015) theorize that diversity may begin to outweigh its positive benefits on adaptive capacity when it comes across a certain threshold. With the case study of the Tam Giang lagoon, we explore empirically if and how types of income diversification can become an impediment for adaptive capacity of smallholders in dealing with environmental change (Darnhofer et al. 2016).

As Kotschy et al. 2015 (using Stirling 2007) point out, there are several aspects of diversity that need to be considered when the aim is to assess the impact of (response) diversity. Diversity can be described in the number of elements present (variety), their relative abundances (balance), or the extent to which they differ from each other (disparity). They even describe livelihood diversity in these terms, i.e., "as the number of options available (variety); the extent to which each option is currently practiced (balance); and the degree of difference between the options (disparity)" (Kotschy et al. 2015:52). All three aspects of diversity affect resilience.

In our case study, we use the concept of response diversity to assess the effect of income diversification on trap dynamics related to poverty and environmental degradation in small-scale fisheries and aquaculture in the Tam Giang lagoon. This lagoon has been identified as an example of a social-ecological trap.

\section{A SOCIAL-ECOLOGICAL TRAP IN THE TAM GIANG LAGOON}

The Tam Giang lagoon, the biggest lagoon of Southeast Asia, is located in Thua Thien Hue province, along the north central coast of Vietnam (Fig. 1). It spans about $70 \mathrm{~km}$ in length and measures 20,000 ha in size. The lagoon receives freshwater from inland rivers 
and connects with the South China Sea through two estuaries. The exchange between freshwater and saltwater creates a rich biodiversity and biomass (Anthony et al. 2009, Tuyen 2010). The lagoon is a crucial source of income for many inhabitants in the province. It is estimated that $30 \%$ of the provincial population earns its living through fisheries and aquaculture (Phap et al. 2002, Tuyen et al. 2010).

Fig. 1. The study sites in the Tam Giang lagoon.

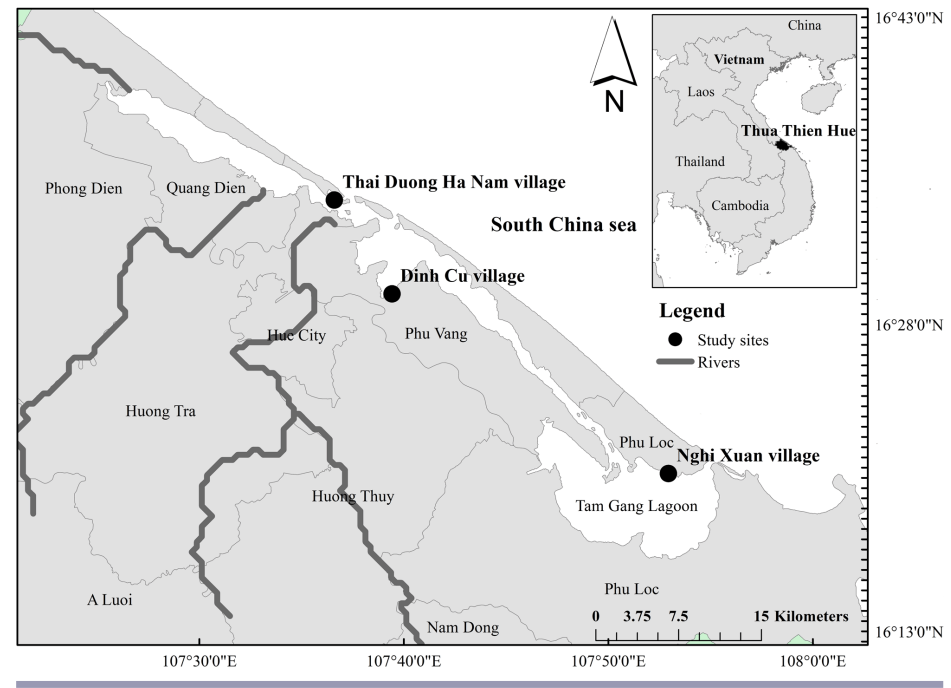

The Tam Giang lagoon is said to represent a larger population of lagoon areas in Southeast Asia that experience trap dynamics related to ecological degradation and impoverishment of well-being (Tuyen et al. 2010, Huong and Berkes 2011, Boonstra and Nhung 2012, Armitage and Marschke 2013, Andrachuk and Armitage 2015, Boonstra and Hanh 2015, Ho et al. 2015). Armitage and Marschke (2013) were probably the first to claim that the lagoon had entered a social-ecological trap. Because the historical origins and persistence of the socialecological trap in the Tam Giang lagoon have been described in detail elsewhere (Tuyen et al. 2010, Armitage et al. 2011, Boonstra and Nhung 2012, Ho et al. 2016), we present only a summary (Fig. 2).

Fishing is the traditional livelihood of the lagoon inhabitants. Many of them used to be sampan dwellers, i.e., landless people who lived on boats permanently but since 1985 have settled on land (DaCosta and Turner 2007). Fishers are conventionally categorized into two groups: so-called fixed fishers and mobile fishers. Fixed fishers are those who use stationary fishing gear, e.g., stake traps and bottom nets. They put their gear permanently into the lagoon and have an exclusive right to the occupied areas. Mobile fishers use mobile fishing gear, e.g., gill nets and steel-framed bottom traps. They can only put their gear in places in the lagoon that are not occupied by fixed fishing gear and aquaculture. Because fixed fishers can claim exclusive rights to designated areas in the lagoon, they are better able to secure catches and profits. For this reason, they are generally considered as better off compared with mobile fishers for whom access and control of lagoon resources is much more insecure (Tuyen 2002, Tuyen et al. 2010).

Prior to 1975, the management of lagoon resources was decentralized to so-called van chai, organized groups of fishers having the same residential registration and using the same type of fishing gear (Nguyen and Ruddle 2010). Van chai leased out fishing locations via auction and organized taxation of their use. They also developed their own regulations to protect the resources within their jurisdiction, through, e.g., regulations on mesh net size and user rights. In 1975, the socialist state collectivized all natural resources, which meant that the management through van chai switched to local governmental organizations, such as the Commune or the District People's Committee (Hong et al. 2000). Several authors point out that this shift in government created an institutional vacuum through which access and exploitation of the lagoon transferred to a regime of de facto open access (Tuyen 2002). As a result, fishers took this opportunity to appropriate fixed fishing locations and claim their ownership informally.

A decade later followed the introduction of nylon fishing nets and the implementation of Doi Moi (Fig. 3). Doi Moi is the name for economic reforms initiated in 1986 with the goal of creating a socialist-oriented market economy, which connected Vietnam to global markets. With nylon nets, fishing became easier, cheaper, and more productive (Boonstra and Nhung 2012); Doi Moi policies increased the price of seafood because of increased international demand. These institutional, technological, and economic changes transformed the lagoon, especially because they occurred at a time when the population in the lagoon was growing. The result was that more people became involved in fishing, and more fish was harvested. The number of fishers increased from 5575 in 1982 to 9120 in 1993 (Brzeski 1996). The number of stake traps increased from 450 in 1984 to 2000 in 1997 (Fisheries Department 2007, cited in Ho 2010). The total fish catch in the lagoon rapidly increased from $850 \mathrm{t}$ in 1976 to 2112 $t$ in 1993, whereas fish catch per household experienced a growing decline since the early 1990s (Boonstra and Hanh 2015; Ho et al. 2016).

By the start of the 1990s, the Vietnamese government introduced and facilitated the development of aquaculture to improve livelihood security and reduce poverty (Fig. 3). Since then, the lagoon has been used extensively for aquacultural production: aquaculture expanded from 20 ha in 1990 to about 4200 ha in 2006 (Thua Thien Hue statistics office 2007). This rapid expansion caused the water quality in the lagoon to deteriorate (Hop et al. 2005, Thung 2007). The nutrient loads from excess feed, shrimp waste, and chemicals washed out into the lagoon leading to eutrophication, higher levels of coliform density, and higher levels of organochlorine pesticides (Truong et al. 2014). The deteriorated water quality in turn negatively affected aquacultural harvests, which deepened the debts of aquaculturists (Integrated Management of Lagoon Activities 2006). Moreover, the expansion of aquaculture reduced the locations and size of nursery areas as well as fishing grounds, which together decreased household fish catches (Tuyen et al. 2010). Fish stocks and water quality were also negatively affected by discharges from agriculture and residential areas (Nhung 2016) and effects of climate change, such as changing flood regimes (Boonstra and Hanh 2015). When households failed to find alternative sources of income, they often increased and intensified their use of the lagoon resources to compensate for declining catches or aquaculture yields. 
Fig. 2. Causal loop diagram of the social-ecological trap in the Tam Giang lagoon. Note: "+" indicates reinforcing feedbacks.

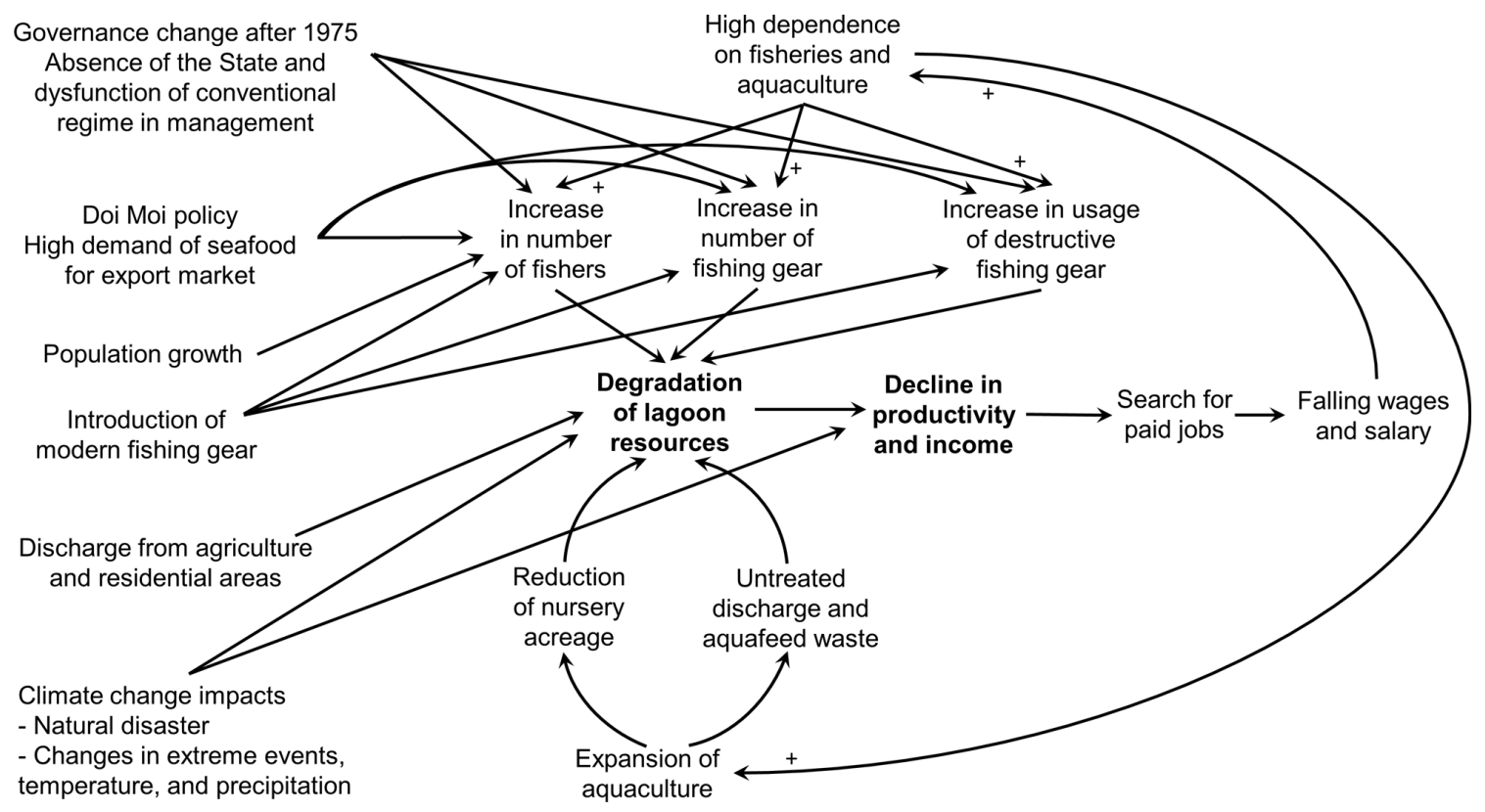

Fig. 3. Key social-ecological changes in the Tam Giang lagoon between 1985 and 2015 .

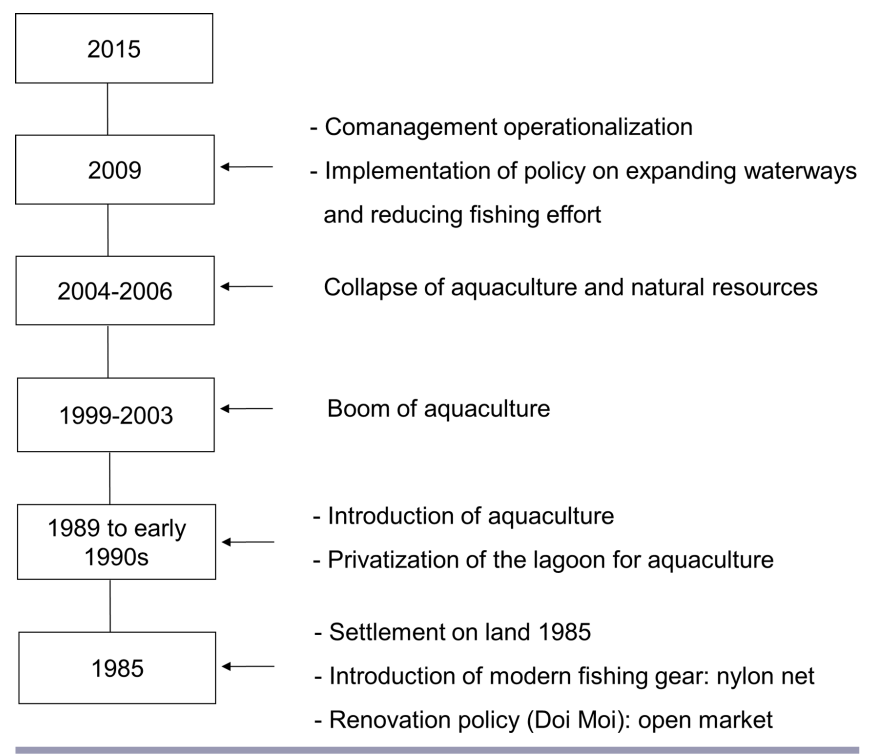

Addressing the social-ecological trap dynamics as described here requires an integrated approach that incorporates multiple management, conservation, and livelihood alternatives (Pomeroy 2012). Some scholars (Allison and Ellis 2001, Ellis and Allison 2004, Brugère et al. 2008) argue that although management and conservation can postpone degradation, livelihood alternatives help to reduce pressure on natural resources and improve livelihoods. So far, a few studies have investigated livelihood alternatives in relation to trap dynamics in the Tam Giang lagoon
(Boonstra and Hanh 2015, Betcherman and Marschke 2016). Boonstra and Hanh (2015) especially point out that income diversification could get the resource users more entrapped. We contribute to this body of literature by using the concept of response diversity to explore in more detail how various local user groups diversify their income activities in response to socialecological trap dynamics.

\section{METHODOLOGY}

Our study is based on a qualitative investigation of how income diversifications of primary resource users impact socialecological trap dynamics. We selected three villages, Thai Duong Ha Nam, Dinh $\mathrm{Cu}$, and Nghi Xuan (Fig. 1 and Table 1), to represent the ecological and geographic diversity in the lagoon, as well as the diversity of primary resource users. Thai Duong Ha Nam and Nghi Xuan are located in the north and south end of the lagoon, respectively, which means that both are close to the estuaries and relatively far from urban centers. Although fixed fishing with bottom nets and fish cages dominates livelihood activities in Thai Duong Ha Nam, people in Nghi Xuan mostly rely on stake traps and earth ponds. Dinh $\mathrm{Cu}$ is located in the center of the lagoon, which is far from the estuaries and relatively close to urban centers. Here the lagoon is mainly used for netenclosed aquaculture. Mobile fishing is practiced in all three villages and throughout the lagoon.

In each village, three focus group discussions were conducted with different types of resource users, mobile fishers, fixed fishers, aquaculturists, and net-enclosed aquaculturists. Each focus group discussion consisted of six to eight participants and lasted about 2 to 3 hours. Because most households practice more than one type of resource use, their main income activity was used for categorization in the four groups. The focus group discussion aimed to (1) map social memories of social-environmental 
changes; (2) discuss how the resource users diversify their income sources to respond to the changes that were identified and how diversification changed their income portfolios (here groups estimated the relative proportion of each income activity to their total household income at different points in time; Fig. 4); and (3) examine the impact of these responses on social-ecological trap dynamics (Appendix 1).

Table 1. Demographics of the study sites, disaggregated per resource user group.

\begin{tabular}{lccc}
\hline \hline Villages & $\begin{array}{c}\text { Thai } \\
\text { Duong } \\
\text { Ha Nam }\end{array}$ & $\begin{array}{c}\text { Dinh } \\
\mathrm{Cu}\end{array}$ & $\begin{array}{c}\text { Nghi } \\
\text { Xuan }\end{array}$ \\
\hline Population (heads) & 700 & 778 & 940 \\
Number of households & 180 & 165 & 216 \\
Number of mobile fisher households & 28 & 12 & 40 \\
Number of fixed fisher households & 40 & 0 & 60 \\
Number of aquaculturist households & 60 & 14 & 100 \\
Number of net-enclosed households & 0 & 104 & 0 \\
Number of nonfisheries and & 60 & 30 & 16 \\
aquacultural households & & & \\
\hline
\end{tabular}

Fig. 4. Changes in income portfolio from 1985 to 2015 as estimated by different user groups during focus group interviews.

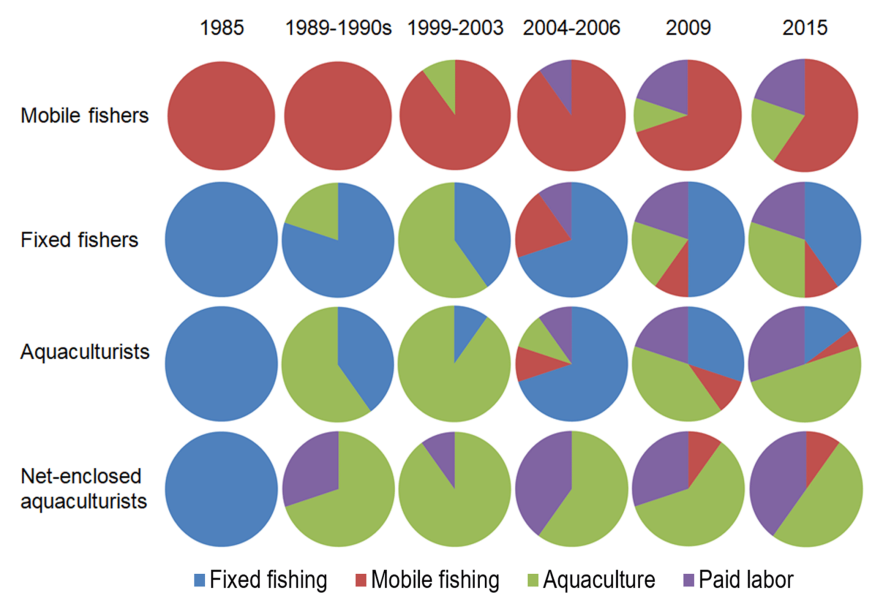

As mentioned, social-ecological trap dynamics result in persistent resource degradation and livelihood impoverishment. Whether response diversity in income diversification can dissolve traps depends on whether it promotes resource regeneration and livelihood improvement. To examine these outcomes of the response diversity, we use the two concepts: ESs and well-being.

ESs are defined as "the benefits people obtain from ecosystems" (Millennium Ecosystem Assessment 2005). ESs include (1) provisioning services for, e.g., food, freshwater, and wood; (2) regulating services, such as flood regulation and water purification; (3) cultural services related to, e.g., aesthetics, education, and recreation; and (4) supporting services, such as soil formation and nutrient cycling. For the assessment of changes in ESs, we first asked respondents to list the various benefits that they received from the lagoon and that they found important for sustenance of their livelihoods, ranking the relative importance of these benefits on a scale from 1 (not important) to 5 (very important). For the benefits scored more than or equal to 3 , we asked respondents to consider changes in the quality and quantity of the ES.

Well-being is defined as "a state of being with others, which arises where human needs are met, where one can act meaningfully to pursue one's goals, and where one can enjoy a satisfactory quality of life" (McGregor 2008:1). Well-being has three independent components: material, which concerns welfare and living standard via variables such as income, assets, employment, and level of consumption; social, which concerns social relations and access to support networks, services, and resources; and human, which concerns capability related to, for example, education, skill, and physical health (White 2010). To assess changes in well-being, we first asked respondents to list indicators of what they considered to be a good life and then to score these aspects on a scale from 1 (not important) to 5 (very important). The indicators scored more than or equal to 3 were chosen for the evaluation of changes, i.e., how people perceive changes and how satisfied they are with these changes.

The changes of selected ESs and well-being indicators were identified according to their peaks. We asked respondents to identify points in time when a service or indicator was perceived as highest: for example, when did you notice that the water in the lagoon was polluted the most, or at which point in time did you obtain your highest household income? These points in time were given 10 marks. Then we asked our respondents how the services and indicators that were identified decreased at other points in time. This exercise confirmed the so-called environmentalist paradox (Raudsepp-Hearne et al. 2010), i.e., that ESs are considered best at the beginning of the timeline in 1985, whereas well-being indicators (except debt) are valued highest in 2015 .

To understand in more detail the differences in income diversification among the various resource user groups and how these differences impacted the ESs and well-being, we performed semistructured interviews with 29 households and 10 local authorities at different administrative levels (Appendix 2). We limited the number of interviews with households after we felt that we reached saturation, i.e., when additional interviews confirmed knowledge from earlier interviews (Guest et al. 2006). Participant observation was also used for triangulation (Laws et al. 2003). The limitation to only 3 villages and a limited number of households restricts the generalization for the context of the Tam Giang lagoon, which consists of 32 villages, and other coastal areas. Nevertheless, we believe that our case study can highlight important dynamics of the relation between income diversification and trap dynamics of social-ecological interactions in the global south.

\section{RESULTS}

\section{Income diversification as response of resource users}

Income diversification is a process whereby households increase the number of income generating activities that they employ (Ellis 2000). As mentioned, the concept of response diversity considers the diversity in response of humans, e.g., resource users. We describe how the four resource user groups identified earlier diversify their income sources as a response to social-ecological changes that were identified during the focus group interviews (Fig. 3). 


\section{Mobile fishers}

This group depends mostly on capture fisheries for their food and income security. Until the middle of the 1980s, mobile fishers typically relied on only one type of mobile fishing gear, e.g. gill nets, dragnets, push nets, mussel rakes, hook and line, and so forth. However, because of the reduction in catches and the better availability of nylon nets and affordable gear, mobile fishers began to diversify their gear and to engage with other income activities besides fisheries, such as aquaculture and paid labor. However, despite these changes, mobile fishing remains the most important source of income for these households.

This group has struggled with two major changes throughout the last 20 years that have reduced its fish catch. First, it has encountered a substantial reduction of fishing grounds because of the expansion of aquaculture starting in the 1990s. Second, it also experienced a significant decline in fish abundance because of overfishing and the deterioration of water quality. Our respondents commented that in the early 2000s they caught one-third of what they used to catch in the 1980s. These households responded to the changes primarily by increasing their fishing effort. Fishers adopted other and newer gear types, including steel-framed bottom traps (Fig. 5), catch methods using electricity, and nets with finer mesh sizes. Somewhat surprisingly, our respondents indicated that currently the majority of the mobile fishers almost exclusively rely on steel-framed bottom traps. The reason is that the catches that can nowadays be obtained with other types of gear are simply too low. Our respondents estimated that their income in 2015 relied $60 \%$ on capture fisheries.

Fig. 5. Steel-framed bottom traps.

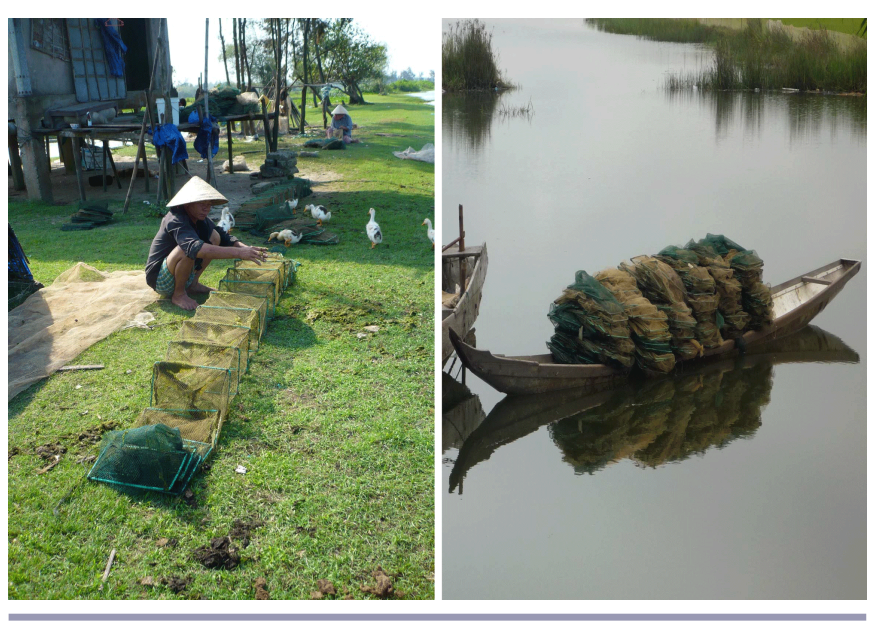

Fishing harder within this group typically occurs because other income opportunities, such as paid labor and aquaculture, are limited. Although aquaculture increased significantly in the lagoon, many mobile fishers were not able to engage in this new income source. The reason is that before the 2000s, aquaculture was based on shrimp monocultures in earth ponds. This system required substantial financial inputs to pay for the construction of the pond, fish meal, and fingerlings. Few households depending on capture fisheries had the funds or collateral to engage in this type of aquaculture production. After the collapse of aquaculture in the late 2000 s, a new system was introduced that is based on mixed stocking to lower the spread of diseases, improve profits, and lower the risk of harvest failure. Despite that the financial requirements for this type of aquaculture production are lower, most households are not able to engage because of the start-up costs: "During the collapse of aquaculture, an earth pond (5000 $\mathrm{m}^{2}$ ) was valued about 10-20 million VND [Vietnamese dong] but no one wanted to buy. Recently, the price soared by 200 million VND per pond but now few aquaculturists want to sell" (head of Giang Xuan Fisheries Association, interview conducted on 27 August 2016). According to the exchange rate in 2017, 1 USD is equivalent to 22,600 VND. Based on our interviews, we estimate that income from aquaculture provided $10 \%-20 \%$ of the household income between 2005 and 2015 .

Opportunities for paid jobs are also limited because of the low level of education in this group. Still, household members sometimes hire themselves out as assistants for street vendors or porters at construction sites. However, access to these types of jobs depends crucially on the household's geographic location, i.e., whether situated close to urban centers, and the physical health of household members. As commented by a 52-year-old mobile fisher in Dinh $\mathrm{Cu}$ village: "Before I worked as hired labor for about 90 days/year. However, the number of wage days reduces by the time. Employers do not want to hire me as I get older and weaker. I probably cannot get any wages in the next 2 years." A 42-year-old mobile fisher living in Thai Duong Ha Nam village said, "I want to hire myself out, but there are no jobs in this remote area."

Another alternative income on which households increasingly rely is having their children migrate to urban centers in search of work (Box 1). When this happens, children drop out of school at the age of 12 , move to cities, and begin to work as, e.g., household maids, assistants of street vendors, or waiters in coffee shops and restaurants. Their incomes are low, which means that they often fail to send remittances home, but at least their livelihood is no longer a cost that the household has to bear. Over time, a majority of these children manage to follow vocational training and educate themselves as bricklayers, carpenters, hairdressers, or workers in garment factories. Paid labor contributed to $10 \%$ of the household income in 2005 and increased to $20 \%$ in 2015.

\section{Box 1:}

Labor migration as coping strategy

"My children migrated for jobs" was a common answer of the four user groups portrayed when asked how they responded to degradation of the lagoon environment. However, not all of their children migrated to the same city and got the same job. The number of young migrants increased dramatically during recent years. According to the head of Nghi Xuan village, only about $10 \%-20 \%$ of the children remain in the village to work as fishers or aquaculturists. However, from our interviews, we believe that the proportion of paid labor income increased slightly. As explained by a fisher in Dinh Cu village: "When children are young, their wage and salary are low. It is often enough for their living in cities. Some even ask for support money from their parents. When they grow up and get higher income, they establish their own households [which means that they then need their income to support their own households]." 


\section{Fixed fishers}

After settlement on land in 1985, fixed fishers depended completely on fixed fishing. The introduction of aquaculture in the late 1980s changed the income portfolio of this group considerably. Fixed fishers chose to invest in aquaculture to accumulate more wealth. In the early 1990s, aquaculture contributed to $20 \%$ of the total income of this group.

The price of shrimp rose substantially since the early 1990s; through the Doi Moi policies, Vietnamese people were then able to supply to an increasing global demand for seafood. The high prices stimulated investments in shrimp aquaculture. Fixed fishers increased stocking densities, from 1-2 to 5-6 shrimp $/ \mathrm{m}^{2}$, and the input of shrimp food to maximize profit. Several fixed fishers converted their stake traps in the middle of the lagoon into net enclosures. Some fixed fishers in the north and south of the lagoon minimized their fishing or stopped fishing altogether to focus completely on aquaculture. As such, their livelihoods changed from being based on fixed fisheries to net-enclosed and earth pond fish farming, respectively. Between 1999 and 2003, aquaculture produced high profits. Households were able to obtain profits of 100 million VND per hectare per year. At this time, the income from aquaculture could constitute $60 \%$ of the total household income.

However, the time of high profits did not last long. Aquaculture collapsed between 2004 and 2006 because of outbreaks of aquatic diseases and environmental pollution. Fixed fishers experienced several years of harvest failures, which greatly indebted them. Households could incur from 50 to 200 million VND in debt. In response to these harvest failures, people turned back to practicing fixed fishing. However, this income generating activity had also become harder because of (1) declines in fish abundance caused by the deterioration of the water quality and overexploitation and (2) stricter regulation from the Vietnamese government. In 2009, the government reduced the number and size of fixed gear by forcing $50 \%$ of the gear to be removed from the lagoon. Moreover, the size of the remaining stake traps had to be reduced by 17\% (Thua Thien Hue PPC 2010, Phu Loc DPC 2011).

Other income opportunities remained limited. Paid labor in the lagoon was not readily available, and just like mobile fishers, fixed fishers lacked the education and skill to obtain jobs. In recent years, parents have chosen to send their children to urban centers for jobs to earn additional income or to fend for themselves. Nowadays, these salaries supply approximately $20 \%$ of the household income.

It follows that fixed fishers predominantly have responded to social-environmental changes through a diversification of fishery and aquaculture practices and increasing their fishing effort. To maximize catches, many fixed fishers also added mobile fishery to their income portfolio, relying on steel-framed bottom traps. In 2015, this type of fishery constituted $50 \%$ of their income. The fixed fishers that continue to practice aquaculture abandoned shrimp monocultures and replaced them with a mixed stocking system whereby several species, including fish, shrimp, and crabs, are stocked in the same pond. These mixed systems help to minimize the disposal of waste, because fish and crabs can eat shrimp's leftovers, and reduce the risk of harvest failures caused by diseases, because the three species carry different diseases and thus cannot contaminate each other. Although this form of aquaculture is more robust than shrimp monocultures, it also yields lower profits. Respondents estimated the profits to be $30 \%-40 \%$ lower compared with the profits they enjoyed with shrimp monocultures during 1999-2003. Nowadays, fixed fishers earn $30 \%$ of their total income from aquaculture.

\section{Aquaculturists}

Aquaculturists used to have fixed fishing as their main income source but during the 1990s switched over to aquaculture instead. The households that made the switch were considered to be economically well off. Their aquaculture acreage was 3-fold or 4fold that of the fixed fishers (commonly 1.5-3 ha per household).

When fish farming proved lucrative during the early 1990s, many aquaculturalists increased their investment in shrimp monocultures. Investments increased dramatically when profits rose. The profits from aquaculture peaked during 1999-2003, which meant that during this time households could earn $90 \%$ of their income from fish farming. When after 2003 this type of aquaculture collapsed, aquaculturists initially reacted by investing more in their aquaculture businesses. These efforts only resulted in deeper debts because the yields did not improve. After 2005 , more and more aquaculturists abandoned their ponds in search of alternative income activities besides aquaculture (Box 2).

In doing so, some aquaculturist households managed to earn income from wage labor, approximately $30 \%$ (in 2015), by sending their children to work in urban centers. The majority of aquaculturist households, however, remained engaged in aquaculture but diversified their ponds through the introduction of other species and production methods. For example, some households that used earth ponds started to breed fish in cages and vice versa. However, these households never experienced the same profits from aquaculture as compared with what they earned during 1999-2003. Many households increased their fishing effort by using fine mesh nets for their fixed fishing gear and applying steel-framed bottom traps. According to an aquaculturalist from the Thai Duong Ha Nam: "Although we expanded our aquaculture acreage and tried to rely on different production methods, we earn only about $40-50 \%$ of what we used to earn with fish farming during 1999-2003. We have to engage more income generating activities to get enough income. Besides applying finer nets to our fixed fishing, we also buy steel-frame bottom traps to practice mobile fishing." Our respondents estimated that in 2015 aquaculture contributed $50 \%$ of the total income, while the income of fixed and mobile fishing amounted to $20 \%$.

\section{Box 2:}

Dealing with debts in aquaculture

"Our family got credit from the bank to dig more earth ponds and to increase the number of shrimp. For this we had to buy more fish meal. With these investments our profit increased up to 100 million VND per hectare after the historic flood in 1999. We kept investing more to get more profit, but suddenly experienced harvest failures in 2004. We tried to get more loans to put in our ponds and expected to regain the profits. Yet we ended up with a huge debt, about 250 million VND. We lost our 
hope in aquaculture and had to find alternatives. We wanted to get paid jobs as we thought they are less risky than aquaculture. However, it is not easy as there are not many jobs and [the jobs that exist we don't get because] we don't have any skills other than fish farming and fishing. We sent our children to cities but we still need to support them because their wages are low. In the end, we rely on the lagoon resources to survive" (An aquaculturist from Nghi Xuan village).

\section{Net-enclosed aquaculturists}

As mentioned, net-enclosed aquaculturists initially worked with fixed gear but converted their stake traps into net enclosures during the early 1990s. This gear conversion was initiated by a conjuncture of successes of aquacultural trials run by state enterprises, favorable conditions for aquaculture, e.g., shallow water levels and abundance of water plants and seaweed, and permissions from the local government to convert to net enclosures (Tuyen 2006). After the conversion, aquaculture became their main income source. Different from other households in other parts of the lagoon, net-enclosed aquaculturists have better opportunities to earn income through paid labor. The close proximity to Hue city provides them with more job opportunities. Women worked as household maids or waitresses for street vendors and restaurants or ran small business, and men worked as porters in construction sites. Our respondents estimated that during the early 1990 s, these wages contributed to approximately $30 \%$ of their total income.

However, when profits from aquaculture increased, these aquaculturists reduced their paid labor to put more labor into their aquaculture business. They also expanded their net enclosures and spent more money buying fingerlings and fish meal. Between 1999 and 2003, the profits from aquaculture contributed to approximately $90 \%$ of their total household income. These profits declined again during the mid-2000s because of the harvest failures in aquaculture mentioned previously. Still, net-enclosed aquaculturists seemed to have been hit less hard and maintained some profit from aquaculture. This difference is explained by net-enclosed aquaculturists in a focus group discussion in Dinh Cu village as follows: "After the 'golden time' [1999-2003] profits from net-enclosed aquaculture dropped from 50 to 300 million VND per year to 5 to 20 million VND per year for each household. However, we rarely have losses. When an epidemic occurs, our net enclosures can still produce some harvest, often enough to recoup investments. This is because net enclosures are larger than earth ponds which disperses the waste and pollutants. Moreover, the water in our net enclosures is cleaner than that in earth ponds so the disease doesn't spread as easily."

Unlike fixed fishers or aquaculturists, net-enclosed aquaculturalists were able to compensate for the loss of profits through paid labor. Around the same time that profits of aquaculture decreased, opportunities for jobs improved because of the creation of several industrial zones in Phu Da and Phu Bai (about $15 \mathrm{~km}$ from Dinh $\mathrm{Cu}$ village). In these zones, some parents worked in the unskilled labor force, and children often engaged in vocational training to get jobs that require skilled labor, e.g., garment workers. Because of these changes in livelihood activities, the income from paid labor increased to $60 \%$ of the total income. Later, the relative importance of paid labor would decrease to $40 \%$ in 2015 relative to the increase of income from fish farming and mobile fishing.

One improvement was introduced at the end of the 2000s when the local government opened and widened waterways between net enclosures. About $40 \%$ of net-enclosed acreage was taken back to open the waterways (Thua Thien Hue PPC 2007). As a result of this intervention, households lost $20 \%-60 \%$ of the areas that they used for aquaculture (head of Phu My 1 Fisheries Association, interview conducted on 23 August 2016). However, the opening of waterways enhanced water circulation, reduced pollution, and as such improved yields for the aquaculture that remained. Nevertheless, profits in aquaculture never improved to the levels during 1999-2003. After these changes, the income from aquaculture contributed to $50 \%$ of household total income in 2015. The expansion of waterways also offered a chance to earn $10 \%$ of the income from mobile fishing, which was impossible before (see also Tuyen et al. 2010).

From these results, it follows that it is important to clearly differentiate between income and livelihood. A livelihood can exist from several different incomes and therefore involve different income sources and occupations. The conventional understanding of livelihood diversification emphasizes the importance of income diversification, as, e.g., in Ellis's (2000:15) definition: "livelihood diversification is defined as the process by which rural households construct an increasingly diverse portfolio of activities and assets." As can be seen in the two subsequent examples, this definition is adapted in much of the literature on diversification in fisheries (e.g., Coulthard 2008, Kasperski and Holland 2013, Olale and Henson 2013, Finkbeiner 2015):

Due to this variability in the ocean environment, many
fishers in the region distribute their risk by engaging in
a variety of fisheries using different gears and traveling
to different locations, and maintaining multiple
livelihoods. (Finkbeiner 2015:141-142)

There are two main ways fishermen can diversify their fishing revenues: by targeting different species or species groups within a region and by fishing in different regions. ... Diversification across multiple fisheries can reduce variation and the associated financial risk. It can also increase the minimum annual revenue relative to average revenue, which should reduce the risk of a business failure. (Kaperski and Holland 2013:2077-2078)

It is clear that the responses described, i.e., fishers using various new gear or fishers shifting to aquaculture, count as examples of income diversification according to its conventional understanding and definition. Subsequently, we will describe how this type of income diversification impacted people's well-being and the resilience of lagoon resources and ecologies.

\section{Changes in ecosystem services and well-being}

Changes in ecosystem services

ESs that respondents believed contributed directly to their income were selected to evaluate their changes over time. These ESs included aquatic species, water, fingerlings, and sea grass. Aquatic species include fish, shrimp, crabs, and oysters, which are fished 
for cash and food. Water and fingerlings, including juvenile fish, shrimp, and crabs, are used for aquaculture. Sea grass is harvested for cash and fodder for aquaculture. Changes of these ESs were assessed according to their quantity (aquatic species, fingerlings, and sea grass), quality (water), and size (aquatic species). The status of the ESs in 1985 was used as a baseline for evaluating the changes.

All of the resource users indicated a significant decline of the key ESs between 1985 and 2015. However, the rate of decline varied depending on the type of ESs and the timing. In general, the rate of decline increased dramatically between 1985 and 2009 and leveled off between 2010 and 2015, but respondents believed it would increase in the next 10 years, as illustrated in the following comments:

\begin{abstract}
In the early 1980s, fish, shrimp and crab were abundant and large. The profitable fish, for example mullet [Mugilidae], and sea bass [Lates calcarifer] were abundant and had sizes from 2 to $5 \mathrm{~kg}$ each. I used 10 gill nets and could catch $10 \mathrm{~kg}$ of fish in 2-3 hours. It was annoying to see crabs enmeshed in my gill nets as no one wanted to buy them, and they damage the gill net. However, I used to come back home with some $\mathrm{kg}$ of crabs. In the early 2000s, I used 40-50 gill nets and spent more time on the lagoon but could only get 3-4 kg of fish per day. Mullet over $1 \mathrm{~kg}$ became rare. I wanted to catch crabs for cash but could get maximum $0.5 \mathrm{~kg}$ per day. Nowadays, although I use 60 steel-framed bottom traps, I only get 1-2 kg of fish per day. I hardly catch a mullet. Getting a few crabs per year becomes my fortune. (Mobile fisher in Nghi Xuan village)
\end{abstract}

Aquaculture was struggling with similar problems: "Due to water pollution, it takes longer and longer to catch fish and shrimp in culture ponds and pens with a size that you could sell. More and more die early" (claimed by net-enclosed aquaculturists).

Since the middle 2000s, the provincial government has tried to halt the degradation through comanagement (Armitage et al. 2011, Armitage and Marschke 2013) and reduction of exploitation efforts. So far, these interventions have not appeared to improve the situation (Ho et al. 2016) because households continue to be highly dependent on the ecosystems in the lagoon. Without alternative livelihoods, the exploitation of the lagoon remains high, or in the words of a fisher in Nghi Xuan village, "We starve if we do not fish hard."

While the use of fixed fishing gear was reduced by half in the late 2000s, mobile fishing gear, especially steel-framed bottom traps, grew exponentially. Both fishers and aquaculturists tried to compensate reduced catches or profits by increasing the use of this type of gear. In 2005, there were 30 households operating 100 steel-framed bottom traps (Thua Thien Hue Fisheries Department, as cited in Duyen, n.d.). In 2009, there were 2399 households using 133,988 steel-framed bottom traps (Thua Thien Hue PPC 2009). To halt this development, the provincial government wanted to reduce the number of traps to 107,700 by 2010 and 75,600 by 2015 (Thua Thien Hue PPC 2009). However, efforts to achieve this goal have so far failed. In 2014, the number of steel-framed bottom traps in only two districts (of the five districts in the lagoon) were about 140,000 (Phu Loc DPC 2014, Quang Dien DPC 2014).
In addition to the increased use of steel-framed bottom traps, fishers also did not comply with regulations regarding the legal mesh size of these traps, and the government was not able to enforce the regulations. A district official explains this noncompliance as follows: "Fishers using steel-framed bottom traps have mesh sizes that are smaller than $9 \mathrm{~mm}[9 \mathrm{~mm}$ is the minimum size that is allowed legally]. But, we cannot penalize offenders because we don't have the means to enforce penalties due to a shortage of human resources" (interview conducted on 22 September 2016).

Moreover, the practice of using steel-framed bottom traps also pollutes the lagoon with toxic chemicals, because the fishers use bleach on the traps. Apparently, bleaching traps improves their fish catching ability. It is estimated that more than $150 \mathrm{~kg}$ of this substance has been released directly to the lagoon every day since the early 2010s (Linh 2013, Khánh 2016).

Considering these changes together, a provincial state official is pessimistic about the near future and describes trap dynamics as follows: "Given the current number of steel-framed bottom traps and non-compliant use of mesh nets, the lagoon resources definitely continue to be degraded and resource users will fall back into poverty in a near future" (head of the provincial department of fisheries resource exploitation and protection, as quoted in Hằng 2012).

So far, we have only considered changes in ESs that originate from within the lagoon system, as, e.g., with intensification of fishing or aquaculture practices. However, history has demonstrated that the lagoon is often also subject to external threats, such as natural disasters (flooding) or pollution through industrial waste (Box $3)$.

\section{Box 3:}

Pollution as an external threat

The impact of external threats on the sustainability and resilience of the lagoon is illustrated in the following example. In 2016, fishers and aquaculturists almost failed to earn an income because of industrial waste discharge from a Taiwanese steel plant, Formosa Ha Tinh (located $400 \mathrm{~km}$ from Thua Thien Hue province to the north). As reported in the press, this steel plant illegally discharged toxic industrial chemicals to the South China Sea, from Ha Tinh province to Thua Thien Hue province (Vietnamese Government 2016). The discharge in turn triggered massive deaths of marine and aquatic species. More than $100 \mathrm{t}$ of fish washed up on the coastal shores of four provinces; about $215 \mathrm{t}$ of aquacultural species died, e.g., shrimp, fish, and shellfish (Vietnamese Government 2016). Moreover, the impacted provinces lost $1600 \mathrm{t}$ of fish catch per month (Vietnamese Government 2016). In the lagoon, fishers almost stopped fishing for several months, and aquaculturists suffered severe losses because of harvest failures and lack of economic demand. Fish prices plunged immediately after the disaster because consumers were skeptical about seafood safety. With respect to this situation, a fisher remarked: "We played cards or did nothing at home as there was nothing to catch and no other jobs to do." An aquaculturist pointed out: "I had to [discount] sale my saleable size fish and accept the loss as I could not bear daily costs for aquafeed while waiting for the price to increase." 


\section{Changes in well-being}

To start with, it should be noted that the research discussed people's experience of well-being in retrospect for the period between 1985 and 2015. This means that at a particular time during this period, well-being might not always be considered as improved. In particular, our respondents experienced a decrease in well-being, e.g., income decline and increasing debts, in the middle of the 2000 s because of failed harvests in aquaculture and diminished fish catches. According to our respondents, four key indicators influence well-being or "a good life": income, the size of debts, housing, and ownership of household appliances and furniture. Despite differences in perception of the changes in the lagoon at different points of time, our respondents agreed that their well-being generally has improved. Their income, housing, and quantity of household appliances and furniture have increased, and debt has been reduced. According to the Nghi Xuan village head: "Our life nowadays is a lot better than it was before. People earn five to six times what they used to. As incomes get higher, people build new houses and buy modern house appliances. All villagers now live in stone houses which are much nicer. They have color televisions. Wood stoves which produced a great deal of smoke and cinder were replaced by gas stoves. The majority of the households have refrigerators to store food. And for getting around people use motorbikes instead of bicycles or walking."

People were satisfied with changes in all the indicators of wellbeing, except for income. Although income progressively increased after the mid-2000s, the satisfaction people experienced remained constant or even decreased. Respondents indicated that they felt that income improvements might not be sufficient to ward off the growing decline of economic efficiency in fishing and aquaculture, as the costs of household expenditures increase. Mobile fishers in Nghi Xuan village explained: "We are not saving as we used to do although we try harder to increase our income. Before the mid-2000s we spent 3-4 hours on the lagoon and used 20-30 gill nets for fishing. At that time, we managed to save money, which we used to build houses. Nowadays, the fishing effort and the number of gears that we use have doubled, or even tripled. We even use more expensive and more effective gear, such as the steel-framed bottom traps, but our income does not grow much. Meanwhile, the prices of food, clothes, electricity, school fees, etc., increased at least double."

In summary, comparing changes in ESs and well-being indicates that although natural resources have deteriorated over the last decades, well-being has improved. At first sight, this would seem to make social-ecological trap dynamics irrelevant for the Tam Giang lagoon, but as the respondents indicate, there is a clear interdependency between natural and human capital. The decrease in natural capital, indicated by declining ESs, has until now been offset by improved fishing technologies, improved market access, migration, and better opportunities for wage labor for certain groups (net-enclosed aquaculturists and some mobile fishers). However, judging from recent experiences, respondents now believe that any increases of profitability through, e.g., rising seafood price or improved catch methods, would fail to compensate for the decline of fish catch and aquacultural yield.

\section{DISCUSSION}

Resource users in the Tam Giang lagoon have diversified their income sources in various ways to cope with reinforcing feedbacks between ecological degradation and livelihood impoverishment. Most typically, parents continue working in the lagoon as fishers or aquaculturists, and their children move to cities in search of work (Box 1). At a community level, different user groups, depending on their own capability, e.g., access to natural resources, physical health, and education, and available opportunities for paid labor, acquired different income sources and portfolios. To generalize these responses, fishers started practicing aquaculture, and aquaculturists got involved in fishing. Apart from fisheries and aquaculture, these groups also engaged in paid labor, albeit to a limited extent.

We confirm that these strategies of income diversification helped to improve resource users' well-being. However, this improvement seems brittle from a social-ecological perspective. Our results indicate that resource users' well-being deteriorated whenever there were changes related to the lagoon ecology, such as during the collapse of aquaculture from 2004 to 2006 and an ecological disaster in 2016 (Box 3). Moreover, we also demonstrated how improvement in well-being through income diversification has been achieved at the expense of the sustainability of lagoon resources. What do these results imply for the assumption that income and livelihood diversification can resolve trap dynamics in situations of poverty and environmental degradation? How can our results help to further qualify the understanding of income diversification as a means to overcome social-ecological traps?

To engage these questions, we analyze the three independent aspects that determine diversity as defined in the literature: variety, balance, and disparity (Stirling 2007, Kotschy et al. 2015). To reiterate, variety refers to the number of elements involved, balance refers to the relative proportion of each element, and disparity concerns the difference between elements. The elements under consideration are the income activities as identified in our case study. We operationalize these three aspects as follows (see also Kotschy et al. 2015).

Variety is the number of income activities available, including fishing with mobile gear; fishing with fixed gear; aquaculture, including fish cages, net enclosures, and fish ponds; and paid labor, skilled and unskilled. Of particular importance is the introduction of aquaculture in the 1990s and the introduction of varied fishing methods, i.e., nylon fishing nets, steel-framed bottom traps, and so forth, which importantly diversified income opportunities for many households. Moreover, our results also demonstrate that household incomes more and more rely on paid wages, often in the form of remittances. Resource users generally maintain a highly varied portfolio of income sources.

Balance refers to the apportionment of these income activities, i.e., the extent to which each of these income activities is practiced and contributes to well-being on a household level. From this perspective, it is clear that earnings from fishing and aquaculture dominate household portfolios. Our results indicate that only a minority of households can tap into substantial income sources that are not related to lagoon ecologies. Because of a lack of paid job opportunities, the only option open to local users is to intensify their fishing or aquaculture. This response is especially clear in the case of households that use mobile gear. In responding to decreasing fish abundance, these fishers nowadays rely almost exclusively on steel-framed bottom traps. The limited ability to create and act on opportunities for income 
diversification and livelihood change reduces overall response diversity for rural households in the lagoon. According to Kotschy et al. (2015), (un)balance can be related to the relative power that human groups can apply. Further research would be needed to ascertain how inequalities in terms of economic, cultural, and social capital (Boonstra 2016) would constitute power for the different user groups in the lagoon.

Disparity is interpreted as the differences in the degree to which income activities draw on ecological and social resources. In other words, disparity concerns whether income diversification is based on resources other than those from the lagoon. Using this interpretation, the disparity in local usage of the lagoon is relatively low because of the dominance of fisheries- and aquaculture-related income activities. Despite the diversity in gear and structures of fisheries and aquaculture, they all depend on the same ESs from the lagoon. The vulnerability stemming from disparity becomes especially clear during environmental changes. History demonstrates (Box 3) that livelihoods, despite recent improvements, can rapidly decline because their income portfolio continues to heavily depend on a few functioning ESs (see also Steneck et al. 2011).

The focus on the three aspects of diversity helps to clarify how high variety in income activities does not necessarily lead to an escape from social-ecological traps. Although variety in income activities in the case of the Tam Giang lagoon is relatively high, the balance is uneven, and the disparity is low, which overall limits the potential of income diversification to contribute to the resolution or mitigation of trap dynamics in this case. This finding contributes to ongoing efforts to further explore the interplay between human response diversity and social-ecological interactive processes, in particular for small-scale fisheries and aquaculture in the global south, which often experience reinforcing cycles between poverty and ecological degradation. Income diversification is often proposed in this context as a way to improve household economies and decrease the direct dependence on natural resources (Allison and Ellis 2001, Ellis and Allison 2004). Especially within fisheries, the diversification and combination of target species, gear, and fishing grounds are often considered as salient strategies for poverty reduction (Olale and Henson 2013), climate change adaptation (Coulthard 2008), and risk mitigation (Kasperski and Holland 2013, Finkbeiner 2015). Although diversification can doubtless serve such purposes, our case study of livelihood change in the Tam Giang lagoon calls for closer attention, especially to aspects of disparity and balance related to income diversification. It triggers questions concerning the relative proportion of each income activity in a household, but also how activities are (differently) connected to natural environments. Income diversification can only sustain natural resources and improve human well-being if it truly transforms livelihoods by connecting local users in new ways to ecologies and societies, e.g., engaging them in livelihoods that draw on other lagoon resources, such as when income is derived from agriculture, keeping livestock, and paid work. It follows that the concept and idea of livelihood diversification can only become useful for sustainability science and assessment if it can be clarified how income activities draw from and impact ecological resources.

\section{CONCLUSION}

In 1987, the Brundtland Commission placed self-reinforcing feedback between poverty and sustainable use of natural resources high on the political agenda. Thirty years later, it is well accepted that these situations should not be simplified as remorseless tragedies (Hardin 1968), but that complex causality characterizes social-ecological traps (Nunan 2015). Trap dynamics are profound when natural resources are commonly owned and managed (Cumming 2018). This is an important reason why small-scale fisheries and aquaculture in the global south are primary production activities that particularly suffer from persistent poverty in combination with ecological degradation (Kittinger et al. 2013).

Studies have demonstrated how income and livelihood diversification is an important strategy of small-scale fishers and aquaculturists in their response to trap dynamics (e.g., Campbell et al. 2006, Muallil et al. 2013, Boonstra and Hanh 2015). Based on these findings, livelihood diversification is often held up as a salient method for coping with traps, and possibly even preventing or escaping them (Allison and Ellis 2001).

We have built on this literature to further scrutinize the effect of income diversification on trap dynamics in small-scale fisheries and aquaculture in the global south. For this purpose, we applied the concept of response diversity in a case study of livelihood and income diversification in the Tam Giang lagoon, central Vietnam. We demonstrated that having various incomes and livelihood portfolios contributed to increased well-being, but these forms of livelihood diversification continued to rely on similar lagoon resources, which in turn left the social-ecological trap intact (see also Stoop et al. 2016) leaving livelihoods vulnerable to sudden environmental changes from, e.g., flooding or pollution.

Using response diversity as an analytical lens enabled us to qualify strategies of income diversity in terms of their variety, i.e., how many income activities are possible; balance, the relative contribution of different income activities to the total income portfolio; and disparity, how income activities draw on different local ecologies. From this analysis, we concluded that the income diversification occurring in the Tam Giang lagoon does not contribute to the resolution of trap dynamics. Although there exist a variety of income activities, in reality people's capacities and opportunities are limited, which means that they continue to fall back on only a few basic incomes. Strategies to obtain an income from fishing and aquaculture are being continuously diversified by utilizing new techniques, new target species, or monetary investments. However, these main income strategies continue to strongly rely on a limited number of lagoon resources and habitats. The overall unbalance and low disparity in the livelihood portfolios of households in the Tam Giang lagoon limit the potential of income diversification to contribute to the resolution or mitigation of trap dynamics in this case.

This finding demonstrates how income diversification can contribute to the resilience of rural livelihoods, as well as the resilience of social-ecological traps. Although the former is deemed desirable from a development perspective, the latter is not. Attention to response diversity helps to capture these two dimensions into one perspective.

Responses to this article can be read online at: http://www.ecologyandsociety.org/issues/responses. php/10207 


\section{Acknowledgments:}

We are grateful to the reviewers and editors of Ecology and Society, as well as Ashley Perl, for helpful comments and suggestions. We also thank Orn-uma Polpanich for help with designing a map of the Tam Giang lagoon. Finally, we thank the people of the Tam Giang lagoon that were interviewed for the time and information they were willing to share with us. The preparation of this publication was funded by the European Commission and Uppsala University. This publication reflects the views only of the authors, and the commission and university cannot be held responsible for any use that may be made of the information contained therein.

\section{LITERATURE CITED}

Allison, E. H., and F. Ellis. 2001. The livelihoods approach and management of small-scale fisheries. Marine Policy 25 (5):377-388. http://dx.doi.org/10.1016/S0308-597X(01)00023-9

Andrachuk, M., and D. Armitage. 2015. Understanding socialecological change and transformation through community perceptions of system identity. Ecology and Society 20(4):26. http://dx.doi.org/10.5751/ES-07759-200426

Anthony, A., J. Atwood, P. August, C. Byron, S. Cobb, C. Foster, C. Fry, A. Gold, K. Hagos, L. Heffner, D. Q. Kellogg, K. LellisDibble, J. J. Opaluch, C. Oviatt, A. Pfeiffer-Herbert, N. Rohr, L. Smith, T. Smythe, J. Swift, and N. Vinhateiro. 2009. Coastal lagoons and climate change: ecological and social ramifications in the U.S. Atlantic and Gulf coast ecosystems. Ecology and Society 14(1):8. http://dx.doi.org/10.5751/ES-02719-140108

Armitage, D., and M. Marschke. 2013. Assessing the future of small-scale fishery systems in coastal Vietnam and the implications for policy. Environmental Science \& Policy 27:184-194. http://dx.doi.org/10.1016/j.envsci.2012.12.015

Armitage, D., M. Marschke, and T. van Tuyen. 2011. Early-stage transformation of coastal marine governance in Vietnam? Marine Policy 35(5):703-711. http://dx.doi.org/10.1016/j.marpol.2011.02.011

Barbier, E. B. 2015. Climate change impacts on rural poverty in low-elevation coastal zones. Estuarine, Coastal and Shelf Science 165:A1-A13. http://dx.doi.org/10.1016/j.ecss.2015.05.035

Barrett, C. B. 2008. Smallholder market participation: concepts and evidence from eastern and southern Africa. Food Policy 33 (4):299-317. http://dx.doi.org/10.1016/j.foodpol.2007.10.005

Barrett, C. B., P. P. Marenya, J. Mcpeak, B. Minten, F. Murithi, W. Oluoch-Kosura, F. Place, J. C. Randrianarisoa, J. Rasambainarivo, and J. Wangila. 2006. Welfare dynamics in rural Kenya and Madagascar. Journal of Development Studies 42 (2):248-277. http://dx.doi.org/10.1080/00220380500405394

Béné, C., B. Hersoug, and E. H. Allison. 2010. Not by rent alone: analysing the pro-poor functions of small-scale fisheries in developing countries. Development Policy Review 28(3):325-358. http://dx.doi.org/10.1111/j.1467-7679.2010.00486.x

Betcherman, G., and M. Marschke. 2016. Coastal livelihoods in transition: how are Vietnamese households responding to changes in the fisheries and in the economy? Journal of Rural Studies 45:24-33. http://dx.doi.org/10.1016/j.jrurstud.2016.02.012
Biggs, R., M. Schlüter, D. Biggs, E. L. Bohensky, S. BurnSilver, G. Cundill, V. Dakos, T. M. Daw, L. S. Evans, K. Kotschy, A. M. Leitch, C. Meek, A. Quinlan, C. Raudsepp-Hearne, M. D. Robards, M. L. Schoon, L. Schultz, and P. C. West. 2012. Toward principles for enhancing the resilience of ecosystem services. Annual Review of Environment and Resources 37(1):421-448. http://dx.doi.org/10.1146/annurev-environ-051211-123836

Boonstra, W. J. 2016. Conceptualizing power to study socialecological interactions. Ecology and Society 21(1):21. http://dx. doi.org/10.5751/ES-07966-210121

Boonstra, W. J., E. Björkvik, L. J. Haider, and V. Masterson. 2016. Human responses to social-ecological traps. Sustainability Science 11(6):877-889. http://dx.doi.org/10.1007/s11625-016-0397$\underline{x}$

Boonstra, W. J., and T. T. H. Hanh. 2015. Adaptation to climate change as social-ecological trap: a case study of fishing and aquaculture in the Tam Giang Lagoon, Vietnam. Environment, Development and Sustainability 17(6):1527-1544. http://dx.doi. org/10.1007/s10668-014-9612-Z

Boonstra, W. J., and P. T. H. Nhung. 2012. The ghosts of fisheries management. Journal of Natural Resources Policy Research 4 (1):1-25. http://dx.doi.org/10.1080/19390459.2012.642634

Brugère, C., K. Holvoet, and E. H. Allison. 2008. Livelihood diversification in coastal and inland fishing communities: misconceptions, evidence and implications for fisheries management. Working paper, Sustainable Fisheries Livelihoods Programme. Food and Agriculture Organization of the United Nations/Department of International Development of the United Kingdom, Rome, Italy.

Brzeski, V. J. 1996. Shocking fishing in Tam Giang lagoon Vietnam. SAMUDRA Report 15. International Collective in Support of Fishworkers (ICSF), Chennai, Tamil Nadu, India.

Campbell, J., E. Whittingham, and P. Townsley. 2006. Responding to coastal poverty: should we be doing things differently or doing different things? Pages 274-292 in C. T. Hoanh, T. P. Tuong, J. W. Gowing, and B. Hardy, editors. Environment and livelihoods in tropical coastal zones. CABI, Wallingford, UK. http://dx.doi. org/10.1079/9781845931070.0274

Carter, M. R., P. D. Little, T. Mogues, and W. Negatu. 2007. Poverty traps and natural disasters in Ethiopia and Honduras. World Development 35(5):835-856. http://dx.doi.org/10.1016/j. worlddev.2006.09.010

Cinner, J. E. 2011. Social-ecological traps in reef fisheries. Global Environmental Change 21(3):835-839. http://dx.doi.org/10.1016/ j.gloenvcha.2011.04.012

Cinner, J. E., and Ö. Bodin. 2010. Livelihood diversification in tropical coastal communities: a network-based approach to analyzing 'livelihood landscapes.' PLoS ONE 5(8):e11999. http:// dx.doi.org/10.1371/journal.pone.0011999

Cinner, J. E., T. R. McClanahan, T. M. Daw, N. A. J. Graham, J. Maina, S. K. Wilson, and T. P. Hughes. 2009. Linking social and ecological systems to sustain coral reef fisheries. Current Biology 19(3):206-212. http://dx.doi.org/10.1016/j.cub.2008.11.055 
Coulthard, S. 2008. Adapting to environmental change in artisanal fisheries - insights from a south India lagoon. Global Environmental Change 18:479-489. https://doi.org/10.1016/j. gloenvcha.2008.04.003

Coulthard, S. 2012. Can we be both resilient and well, and what choices do people have? Incorporating agency into the resilience debate from a fisheries perspective. Ecology and Society 17(1):4. http://dx.doi.org/10.5751/ES-04483-170104

Coulthard, S., and E. Britton. 2015. Waving or drowning: an exploration of adaptive strategies amongst fishing households and implications for wellbeing outcomes. Sociologia Ruralis 55 (3):275-290. http://dx.doi.org/10.1111/soru.12093

Cumming, G. S. 2018. A review of social dilemmas and socialecological traps in conservation and natural resource management. Conservation Letters 11:e12376. http://dx.doi. org/10.1111/conl.12376

Cumming, G. S., A. Buerkert, E. M. Hoffmann, E. Schlecht, S. von Cramon-Taubadel, and T. Tscharntke. 2014. Implications of agricultural transitions and urbanization for ecosystem services. Nature 515(7525):50-57. http://dx.doi.org/10.1038/nature13945

DaCosta, E., and S. Turner. 2007. Negotiating changing livelihoods: the sampan dwellers of Tam Giang Lagoon, Việt Nam. Geoforum 38(1):190-206. http://dx.doi.org/10.1016/j. geoforum.2006.08.003

Darnhofer, I., C. Lamine, A. Strauss, and M. Navarrete. 2016. The resilience of family farms: towards a relational approach. Journal of Rural Studies 44:111-122. http://dx.doi.org/10.1016/j. jrurstud.2016.01.013

Dasgupta, S., U. Deichmann, C. Meisner, and D. Wheeler. 2005. Where is the poverty-environment nexus? Evidence from Cambodia, Lao PDR, and Vietnam. World Development 33 (4):617-638. http://dx.doi.org/10.1016/j.worlddev.2004.10.003

Duraiappah, A. K. 1998. Poverty and environmental degradation: a review and analysis of the nexus. World Development 26 (12):2169-2179. http://dx.doi.org/10.1016/S0305-750X(98)00100-4

Duyen, N. C. No date. Tác động của nghề lừ lên hệ đầm phá Tam Giang - Cà̀u Hai [Impacts of steel-frame bottom traps on the Tam Giang lagoon resources]. Hue Center for Social Sciences and Humanities, Hue, Vietnam.

Ellis, F. 2000. Rural livelihoods and diversity in developing countries. Oxford University Press, Oxford, UK.

Ellis, F., and E. Allison. 2004. Livelihood diversification and natural resource access. Livelihood Support Programme Working Paper 9. Food and Agriculture Organization of the United Nations, Rome, Italy.

Elmqvist, T., C. Folke, M. Nyström, G. Peterson, J. Bengtsson, B. Walker, and J. Norberg. 2003. Response diversity, ecosystem change, and resilience. Frontiers in Ecology and the Environment 1(9):488-494. http://dx.doi.org/10.1890/1540-9295(2003)001[0488: RDECAR]2.0.CO;2

Fabinyi, M., L. Evans, and S. J. Foale. 2014. Social-ecological systems, social diversity, and power: insights from anthropology and political ecology. Ecology and Society 19(4):28. http://dx.doi. org/10.5751/ES-07029-190428
Finkbeiner, E. M. 2015. The role of diversification in dynamic small-scale fisheries: lessons from Baja California Sur, Mexico. Global Environmental Change 32:139-152. http://dx.doi. org/10.1016/j.gloenvcha.2015.03.009

Folke, C., J. Colding, and F. Berkes. 2003. Synthesis: building resilience and adaptive capacity in social-ecological systems. Pages 352-387 in F. Berkes, J. Colding, and C. Folke, editors. Navigating social-ecological systems: building resilience for complexity and change. Cambridge University Press, Cambridge, UK. http://dx.doi.org/10.1017/CBO9780511541957.020

Food and Agriculture Organization of the United Nations (FAO). 2014. The state of world fisheries and aquaculture: opportunities and challenges. FAO, Rome, Italy.

Fraser, E. D. G., W. Mabee, and O. Slaymaker. 2003. Mutual vulnerability, mutual dependence: the reflexive relation between human society and the environment. Global Environmental Change 13(2):137-144. http://dx.doi.org/10.1016/S0959-3780(03) $\underline{00022-0}$

Guest, G., A. Bunce, and L. Johnson. 2006. How many interviews are enough? An experiment with data saturation and variability. Field Methods 18(1):59-82. https://doi.org/10.1177/1525822X05279903

Haider, L. J., W. J. Boonstra, G. D. Peterson, and M. Schlüter. 2018. Traps and sustainable development in rural areas: a review. World Development 101, 311-321. http://dx.doi.org/10.1016/j. worlddev.2017.05.038

Hằng, M. 2012. Phú Lộc chưa nghiêm trong quản lý nghề lừ [Steelframe bottom trap management in Phu Loc is not serious enough]. Thừa Thiên Huế. 4 September. [online] URL: http:// baothuathienhue.vn/phu-loc-chua-nghiem-trong-quan-ly-nghe-lua3625.html

Hardin, G. 1968. The tragedy of the commons. Science 162 (3859):1243-1248. http://dx.doi.org/10.1126/science.162.3859.1243

Ho, N. T. T. 2010. Những thay đổi trong công nghệ khai thác thủy sản ở vùng đầm phá Tam Giang. Magazine of Thuy San Vietnam. 2 July. [online] URL: http://www.khafa.org.vn/?cmd=newspub\&cmdid= newspub-detail\&idnew $=1481$

Ho, N. T. T., H. Ross, and J. Coutts. 2015. Power sharing in fisheries co-management in Tam Giang Lagoon, Vietnam. Marine Policy 53:171-179. http://dx.doi.org/10.1016/j.marpol.2014.12.006

Ho, N. T. T., H. Ross, and J. Coutts. 2016. Evaluation of social and ecological outcomes of fisheries co-management in Tam Giang Lagoon, Vietnam. Fisheries Research 174:151-159. http:// dx.doi.org/10.1016/j.fishres.2015.09.013

Hong, N. X., T. V. Tuan, and T. T. Phap. 2000. A historical perspective on the management of lagoon resources. Pages 39-53 in V. J. Brzeski and G. F. Newkirk, editors. Lessons from the lagoon: research towards community based coastal resources management in Tiam Giang Lagoon Viet Nam. Coastal Resources Research Network. Dalhousie University, Halifax, Nova Scotia, Canada.

Hop, N. V., N. H. Phong, and T. C. To. 2005. Chất lượng nước đầm phá Tam Giang - Cầu Hai: Hiện trạng, lo lắng và giải pháp kiểm soát [Quality of water resource in the Tam Giang - Cau Hai lagoon]. Pages 306-322 in Do Nam, editor. Kỷ yếu hội thảo quốc gia về đầm phá Thừa Thiên Huế [Proceedings of the National 
Conference on Thua Thien Hue lagoon]. Department of Science and Technology, Thua Thien Hue province, Hue, Vietnam.

Huong, T. T. T., and F. Berkes. 2011. Diversity of resource use and property rights in Tam Giang Lagoon, Vietnam. International Journal of the Commons 5(1):130-149. http://dx.doi.org/10.18352/ ijc. 236

Integrated Management of Lagoon Activities (IMOLA). 2006. Socio-economic baseline survey of Hue lagoon. Part I, survey report. The Network of Aquaculture Centres in Asia-Pacific, Hanoi, Vietnam.

Kasperski, S., and D. S. Holland. 2013. Income diversification and risk for fishermen. Proceedings of the National Academy of Sciences of the United States of America 110(6):2076-2081. http:// dx.doi.org/10.1073/pnas. 1212278110

Khánh, N. 2016. Nhan nhản hóa chất tẩy lừ [Incalculability of chemicals for cleaning steel-frame bottom traps]. Thừ $a$ Thiên $H u$ ê. 8 January. [online] URL: http://baothuathienhue.vn/nhannhan-hoa-chat-tay-lu-a19733.html

Kittinger, J. N., E. M. Finkbeiner, N. C. Ban, K. Broad, M. H. Carr, J. E. Cinner, S. Gelcich, M. L. Cornwell, J. Z. Koehn, X. Basurto, R. Fujita, M. R. Caldwell, and L. B. Crowder. 2013. Emerging frontiers in social-ecological systems research for sustainability of small-scale fisheries. Current Opinion in Environmental Sustainability 5(3-4):352-357. http://dx.doi. org/10.1016/j.cosust.2013.06.008

Kotschy, K., R. Biggs, T. Daw, C. Folke, and P. West. 2015. Principle 1: maintain diversity and redundancy. Pages 50-79 in $\mathrm{R}$. Biggs, M. Schlüter, M. L. Schoon, editors. Principles for building resilience: sustaining ecosystem services in social-ecological systems. Cambridge University Press, Cambridge, UK.

Laborde, S., A. Fernández, S. C. Phang, I. M. Hamilton, N. Henry, H. C. Jung, A. Mahamat, M. Ahmadou, B. K. Labara, S. Kari, M. Durand, B. Mark, P. Scholte, N. Xiao, R. Ziebe, and M. Moritz. 2016. Social-ecological feedbacks lead to unsustainable lock-in in an inland fishery. Global Environmental Change 41:13-25. http://dx.doi.org/10.1016/j.gloenvcha.2016.08.004

Laws, S., C. Harper, and R. Marcus. 2003. Research for development: a practical guide. Sage, New Delhi, India. http://dx. doi.org/10.4135/9781849209786

Leslie, P., and J. T. McCabe. 2013. Response diversity and resilience in social-ecological systems. Current Anthropology 54 (2):114-143. http://dx.doi.org/10.1086/669563

Linh, K. 2013. Nỗi lo suy kiệt nguồn lợi thủy sản [Anxiety of fisheries resource degradation]. Biên phòng. 20 December. [online] URL: http://www.bienphong.com.vn/noi-lo-suy-kiet-nguon-loithuy-san/

Lybbert, T. J., C. B. Barrett, S. Desta, and D. L Coppock. 2004. Stochastic wealth dynamics and risk management among a poor population. Economic Journal 114(498):750-777. http://dx.doi. org/10.1111/j.1468-0297.2004.00242.X

Marschke, M., and G. Betcherman. 2016. Vietnam's seafood boom: economic growth with impoverishment? Environment, Development and Sustainability 18(4):1129-1150. http://dx.doi. org/10.1007/s10668-015-9692-4
McGregor, J. 2008. Wellbeing, poverty and conflict. Research Group on Wellbeing in Developing Countries (WeD) Briefing Paper 1/08. University of Bath, Bath, UK.

Millennium Ecosystem Assessment. 2005. Ecosystems and human well-being: synthesis. Island, Washington, D.C., USA.

Mori, A. S., T. Furukawa, and T. Sasaki. 2013. Response diversity determines the resilience of ecosystems to environmental change. Biological Reviews 88(2):349-364. http://dx.doi.org/10.1111/ brv. 12004

Muallil, R. N., D. Cleland, and P. M. Aliño. 2013. Socioeconomic factors associated with fishing pressure in small-scale fisheries along the West Philippine Sea biogeographic region. Ocean \& Coastal Management 82:27-33. http://dx.doi.org/10.1016/j. ocecoaman.2013.04.013

Nguyen, D. T., and K. Ruddle. 2010. Vietnam: the van chai system of social organization and fisheries community management. Pages 129-160 in K. Ruddle and A. Satria, editors. Managing coastal and inland waters. Springer, Dordrecht, The Netherlands. http://dx.doi.org/10.1007/978-90-481-9555-8 6

Nhung, P. T. H. 2016. Conflicts over natural resources and environment: a case of Tam Giang lagoon in the Thua Thien Hue province, central coast of Vietnam. Dissertation. University of Newcastle, Callaghan, New South Wales, Australia.

Nunan, F. 2015. Understanding poverty and the environment: analytical frameworks and approaches. Routledge, London, UK.

Olale, E., and S. Henson. 2013. The impact of income diversification among fishing communities in Western Kenya. Food Policy 43:90-99. http://dx.doi.org/10.1016/j.foodpol.2013.08.008

Orr, Y., J. S. Lansing, and M. R. Dove. 2015. Environmental anthropology: systemic perspectives. Annual Review of Anthropology 44(1):153-168. http://dx.doi.org/10.1146/annurevanthro-102214-014159

Petchey, O. L., and K. J. Gaston. 2006. Functional diversity: back to basics and looking forward. Ecology Letters 9(6):741-758. http://dx.doi.org/10.1111/j.1461-0248.2006.00924.x

Phap, T. T., L. V. Mien, and L. T. N. Thuan. 2002. Sustainable development of aquaculture in Tam Giang lagoon. Pages 27-37 in V. J. Brzeski and G. F. Newkirk, editors. Lessons in resource management from the Tam Giang Lagoon. Coastal Resources Research Network, Dalhousie University, Halifax, Nova Scotia, Canada.

Phu Loc District People's Committee (DPC). 2011. Báo cáo tổng kết công tác giải tỏa, sắp xếp nò sáo trên phá Tam Giang huyện Phú Lộc [Achievements of the removability and rearrangement of stake traps in Phu Loc district]. Phu Loc DPC, Phu Loc District, Vietnam.

Phu Loc District People's Committee (DPC). 2014. Ủy ban nhân dân huyện họp soát xét tình hình quản lýnghề Lừ xếp trên khu vực đầm phá Cầu Hai - Lăng Cô [Meeting on management of steelframe bottom traps]. Phu Loc DPC, Phu Loc District, Vietnam.

Pomeroy, R. S. 2012. Managing overcapacity in small-scale fisheries in Southeast Asia. Marine Policy 36(2):520-527. http:// dx.doi.org/10.1016/j.marpol.2011.10.002 
Quang Dien District People's Committee (DPC). 2014. Ổn định nghề khai thác lưới lừ dù khó vấn quyết làm [Efforts to stabilize the number of steel-frame bottom traps]. Quang Dien DPC, Quang Dien District, Vietnam.

Raudsepp-Hearne, C., G. D. Peterson, M. Tengö, E. M. Bennett, T. Holland, K. Benessaiah, G. K. MacDonald, and L. Pfeifer. 2010. Untangling the environmentalist's paradox: why is human well-being increasing as ecosystem services degrade? BioScience 60:576-589. http://dx.doi.org/10.1525/bio.2010.60.8.4

Steneck, R. S., T. P. Hughes, J. E. Cinner, W. N. Adger, S. N. Arnold, F. Berkes, S. A. Boudreau, K. Brown, C. Folke, L. Gunderson, P. Olsson, M. Scheffer, E. Stephenson, B. Walker, J. Wilson, and B. Worm. 2011. Creation of a gilded trap by the high economic value of the Maine lobster fishery. Conservation Biology 25(5):904-912. http://dx.doi.org/10.1111/j.1523-1739.2011.01717. $\underline{\mathrm{X}}$

Stirling, A. 2007. A general framework for analysing diversity in science, technology and society. Journal of the Royal Society Interface 4(15):707-719. http://dx.doi.org/10.1098/rsif.2007.0213

Stoop, N., R. Houssa, and M. Verpoorten. 2016. To fish or not to fish? Resource degradation and income diversification in Benin. Environment and Development Economics 21(5):669-689. http://dx.doi.org/10.1017/S1355770X16000012

Swallow, B. M., J. K. Sang, M. Nyabenge, D. K. Bundotich, A. K. Duraiappah, and T. B. Yatich. 2009. Tradeoffs, synergies and traps among ecosystem services in the Lake Victoria basin of East Africa. Environmental Science \& Policy 12(4):504-519. http://dx. doi.org/10.1016/j.envsci.2008.11.003

Thua Thien Hue Provincial People's Committee (PPC). 2007. Quyết định số $1068 / Q Đ-U B N D$ về việc phê duyệt Dự án Quy hoạch sản xuất thuỷ sản đầm Sam Chuồn đến năm 2010, định hướng đến năm 2020. [Decision number 1068/QĐ-UBND on approving the Sam Chuon lagoon planning between 2010 and 2020]. Thua Thien Hue PPC, Hue, Vietnam.

Thua Thien Hue Provincial People's Committee (PPC). 2009. Chỉ thị số $4818 / U B N D-N N$ về việc tăng cường kiểm tra, kiểm soát, quản lý nghề "Lừ xếp" khai thác trên đầm phá [Instruction number 4818/UBND-NN on strengthening management of steel-frame bottom traps in the lagoon]. Thua Thien Hue PPC, Hue, Vietnam.

Thua Thien Hue Provincial People's Committee (PPC). 2010. Quyết định số $1135 / Q Đ-U B N D$ về việc phê duyệt kế hoạch giải tỏa và sắp xếp lại nò sáo trên đầm phá huyện Phú Lộc [Decision Number 1135/QĐ-UBND on approving the removability and rearrangement of stake traps in Phu Loc district]. Thua Thien Hue PPC, Hue, Vietnam.

Thua Thien Hue statistics office. 2007. Statistical yearbook. Statistical Publishing House, Hue, Vietnam.

Thung, D. C. 2007. Environment and resources in the Tam Giang - Cau Hai lagoon. Integrated Management of Lagoon Activities (IMOLA), Hue, Vietnam.

Tittonell, P., and K. E. Giller. 2013. When yield gaps are poverty traps: the paradigm of ecological intensification in African smallholder agriculture. Field Crops Research 143:76-90. http:// dx.doi.org/10.1016/j.fcr.2012.10.007

Truong, H., M. Lyne, and K. Woodford. 2014. Managing water pollution to revitalise the shrimp supply chain in Tam Giang Cau Hai Lagoon, Vietnam. UMK Procedia 1:50-56. http://dx.doi. org/10.1016/j.umkpro.2014.07.007

Tuyen, T. V. 2002. Dynamics of property rights in the Tam Giang lagoon. Page 39 in V. J. Brzeski and G. F. Newkirk, editors. Lessons in resource management from the Tam Giang Lagoon. Coastal Resources Research Network, Dalhousie University, Halifax, Nova Scotia, Canada.

Tuyen, T. V. 2006. Scale up of participatory planning for resource governance: a case in Sam Chuon lagoon, Vietnam. In Survival of the commons: mounting challenges and new realities, 11th Biennial Conference of the International Association for the Study of Common Property (Bali, Indonesia, 2006). Indiana University, Bloomington, Indiana, USA. [online] URL: http://dlc.dlib. indiana.edu/dlc/handle/10535/753

Tuyen, T. V. 2010. Quản lý hệ sinh thái đất ngập nước ven biển miền Trung Việt Nam. Pages 9-31 in T. V. Tuyen and L. T. H. Sen, editors. Phát triển đồng quản lý tài nguyên dùng chung ven biển miền Trung Việt Nam [Building co-management of common pool resources in the coastal Central Vietnam]. Agricultural publisher, Hanoi, Vietnam.

Tuyen, T. V., D. Armitage, and M. Marschke. 2010. Livelihoods and co-management in the Tam Giang lagoon, Vietnam. Ocean \& Coastal Management 53(7):327-335. http://dx.doi.org/10.1016/ j.ocecoaman.2010.04.001

van Wesenbeeck, B. K., T. Balke, P. van Eijk, F. Tonneijck, H. Y. Siry, M. E. Rudianto, and J. C. Winterwerp. 2015. Aquaculture induced erosion of tropical coastlines throws coastal communities back into poverty. Ocean \& Coastal Management 116:466-469. http://dx.doi.org/10.1016/j.ocecoaman.2015.09.004

Vietnamese Government. 2016. Báo cáo thiệt hại sự cố môi trường biển miền Trung [Report on social-ecological loss due to the ecological disaster in the central coast]. Vietnamese Government, Hanoi, Vietnam.

White, S. C. 2010. Analysing wellbeing: a framework for development practice. Development in Practice 20(2):158-172. http://dx.doi.org/10.1080/09614520903564199

The World Bank. 2009. Climate change: fisheries and aquaculture in a changing climate. Report No. 83195. The World Bank, Washington, D.C., USA.

World Commission on Environment and Development. 1987. Our common future: report of the World Commission on Environment and Development. UN Documents: Gathering a Body of Global Agreements. Conference of NGOs in Consultative Relationship with the United Nations, New York, New York, USA. [online] URL: http://www.un-documents.net/wced-ocf.htm 
Appendix 1. Questions used in focus group discussions

1. Mapping memory of social-environmental changes.

- When was this village established?

- From that time until now, what were key events that changed the community and your life?

- Why do you think these events are important?

2. Discussing diversification of income sources in relation to the changes that were identified, and how diversification changed their livelihoods. Questions should be used in relation to the key events identified in Question 1. Use questions to let respondents describe contexts before and after key events.

- How many income sources do your households have in this village?

- Within fisheries, how many types of fishing gears do households use in this village? Why do people use these gears? Who fishes in your households? How much money do households earn daily and monthly from fishing?

- Within aquaculture, how many methods are used in this village? Why do people use these methods? How many and which type of species do people farm in this village? Why do you cultivate these species? Who practices aquaculture from the households? How much profit per yield do you earn?

- What kind of paid labor have people performed in this village? Who is performing these jobs in your households? When did they start doing these jobs? How old were they at that time? In which way and where do people get these jobs? Are they good jobs (in terms of producing a stable and sufficient income, and does it include insurances)? Why do people perform these jobs?

- Could you please estimate the percentage each income source contributes to the total income of your household?

3. Assessing ecosystem service changes.

- What benefits do you get from the lagoon?

- Which benefits do you think are important for your livelihood? Why?

- Can you rank these benefits ranging from one (not important) to five (very important)? Can you explain why you evaluated the benefits in this way?

- When in your experience did you notice that the quality and quantity of the benefits of the lagoon were greatest or weakest? And when and how did you notice changes in the quality or quantity of the benefits?

4. Assessing changes in wellbeing.

- Could you please list what constitutes a good life? 
- Could you rank those items or aspects that constitute a good life? Can you rank them from 'not important' (one) to 'very important' (five)? Why did you rank them in this way?

- When in your experience did you notice that the quality and quantity of these items or aspects of a good life were greatest or weakest? (e.g. when was your income highest, or when did you experience your highest debt)? And when and how did you notice changes in the quality or quantity of these items or aspects?

- How do you evaluate these items or aspects currently? Why? 
Appendix 2. Questions used for the semi-structured interviews

We used the key social-ecological changes' that were identified through the focus group discussions to examine the income diversification processes of resource user groups, and how these processes impact ecosystem services (i.e. aquatic species, water quality, fingerlings, and seagrass) and well-being indicators (i.e. income, the level of debts, housing, and ownership of house appliances and furniture).

1. Discussing how the resource users diversify their income sources to respond to the changes that were identified, and how diversification changed their income portfolios and livelihoods.

- How many income sources does your household currently have? Have you always depended on these sources throughout your life time?

- How many types of fishing gears do you use? Why do you use these gears? Have you always used these gears? Who practices fishing in your household? How much money does your household earn daily and monthly from fishing? Has this changed during your life time?

- Do you perform aquaculture? If so, what type? Why do you use these cultivation methods? How many and what kind of aquatic species do you cultivate? Why do you cultivate these species? Who performs aquaculture in your household? How much profit per yield (or year) you earn with aquaculture? Has this changed during your life time?

- What kind of paid labor do you perform? Who performs these jobs in your household? When did you/they start doing these jobs? How old were you/they at that time? How do you/they get these jobs? Are these good jobs (stable, sufficient income, insurance)? Why do you/they take on these jobs? Has this situation changed during your life time?

- Could you estimate how much each income source contributes to your household monthly and annual income? Has this changed during your life time?

2. Assessing ecosystem service changes.

- When did you perceive that aquatic species were most abundant? How did abundance levels change at other points in time, and why do you think these levels changed? (Ask respondents to rank the period with highest abundance level with 10 points, and rank other levels that respondents indicate with corresponding points).

- When did you perceive that the lagoon water was polluted most? How did pollution levels change at other points in time, and why do you think these levels changed? (Ask respondents to rank the period with highest pollution level with 10 points, and rank other levels that respondents indicate with corresponding points). 
- When did you perceive that fingerlings were most abundant? How did abundance levels change at other points in time, and why do you think these levels changed? (Ask respondents to rank the period with highest abundance level with 10 points, and rank other levels that respondents indicate with corresponding points).

- When did you perceive that the seagrass was most abundant? How did abundance levels change at other points in time, and why do you think these levels changed? (Ask respondents to rank the period with highest abundance level with 10 points, and rank other levels that respondents indicate with corresponding points).

- Do you think that your income activities have impacted the changing levels of these benefits? Why?

3. Assessing wellbeing changes.

- How much income did your family earn the previous year? Is this the highest income that you have so far earned? If not when did you earn your highest income? (Ask respondents to rank the year with highest income with 10 points, and rank other years that respondents indicate with corresponding points). Can you explain these income fluctuations?

- How satisfied are you with your current income? Can you explain why?

- How much debt do you carry? Is this the highest debt that you have had? If not when did you owe the highest debt? (Ask respondents to rank the year with highest income with 10 points, and rank other years that respondents indicate with corresponding points). Can you explain these fluctuations of your debt?

- When did you build your house? Is this the most convenient house that you have owned? If not when did you own the most convenient house? What kind of house did you have at this point in time?

- How satisfied are you with your current house? Can you explain why?

- What sort of household goods (e.g. appliances and furniture) does your family currently own? Is this the most household goods you have owned? If not at which other point in time did you own more household goods? (Ask respondents to rank the year with highest income with 10 points, and rank other years that respondents indicate with corresponding points). Can you explain these fluctuations of your household goods?

- How satisfied are you with your current household goods? Can you explain why?

- Do you think that an increase of income sources can helps to improve your life? Why? 